\title{
A EDUCAÇÃO DE JOVENS E ADULTOS: UMA ANÁLISE DAS PUBLICAÇÕES CEDES
} 1997-2018

\author{
Analice Assunção de Souza Nunes*, Sandra Fernandes Leite.
}

\section{Resumo}

Este projeto de Iniciação Científica foi elaborado para estudar a temática Educação de Jovens e Adultos nas publicações do Centro de Estudos Educação e Sociedade CEDES; o Cadernos Cedes e a Revista Educação \& Sociedade.Pelo seu histórico de lutas e debates no cenário nacional, a entidade participa ativamente dos principais fóruns de discussões, contribuindo com reflexões sobre a educação e políticas públicas para a construção de uma sociedade justa, democrática e igualitária.Em virtude da relevância da atuação do CEDES, constata-se a importância de suas publicações para subsidiar e inspirar o diálogo, visando uma educação de qualidade, pública, laica, e para todos. As questões apresentadas sobre o tema EJA nas referidas publicações, para o período de 1997 a 2018, trazem questões sempre pertinentes e atualizadas para os debates necessários a uma prática educacional comprometida com a educação democrática.

Palavras-chave: Educação de Jovens e Adultos, política educacional, educação democrática

\section{Introdução}

O Centro de Estudos Educação e Sociedade (CEDES) foi criado em 1979 por educadores comprometidos com a defesa da educação pública de qualidade para toda a população. Firmou-se como centro de excelência na difusão do conhecimento em educação. A pesquisa visou construir uma série histórica relativa aos artigos publicados entre 1978 e 1996, uma vez que esses circularam apenas na versão impressa. Pretendeu-se verificar em que medida a Educação de Adultos estabeleceu o diálogo direto com as alterações no mundo do trabalho e as categorias analíticas que mais incidiram na produção científica e identificar as principais correntes teóricas presentes nos artigos acerca da Educação de Adultos atualmente modalidade Educação de Jovens e Adultos (EJA) da Educação Básica. A pesquisa foi documental e bibliográfica através do levantamento e análise dos artigos publicados pelo do CEDES: Revista Educação \& Sociedade e Cadernos CEDES. Foram analisadas as publicações do período de 1997 a 2018.

\section{Resultados e Discussão}

Revista Educação \& Sociedade O resultado demonstrou que nos anos de 1997 a 2018 o tema foi abordado com constância em trinta e seis textos, citado nas edições de números $59,60,63,68,72,81,89,92,105,111,112,114$, $115,116,120,122,124,126,131,135,140,142$ e 145 da publicação Revista Educação \& Sociedade. O ano em que o tema foi abordado com mais trabalhos foi em 2011 (edições de número 114, 115 e 116) com sete textos.

Cadernos Cedes $O$ resultado demonstrou que nos anos de 1997 a 2018 o tema foi abordado com constância em trinta e quatro textos, citado nas edições de números 51 , 55, 71, 72, 79, 90, 96, 98 e número especial 35 da publicação Cadernos Cedes. Registrou-se em 2007 (edições de número 71 e 72) nove textos; em 2015 (edições de número 96 e número especial 35) oito textos; em 2016 (edição de número 98) oito textos onde a temática era a educação de jovens e adultos.

\section{Conclusões}

O tema Educação de Jovens e Adultos nas publicações CEDES foi proposto com constância, num total de 70 trabalhos; 36 textos na Revista Educação \& Sociedade e 34 textos nos Cadernos Cedes para o período compreendido entre 1997 e 2018. O levantamento apontou a relevância do tema em anos em que os movimentos de educadores e movimentos sociais mobilizaram-se intensamente para discutir a modalidade EJA. Na Revista Educação \& Sociedade os textos abordando a EJA foram numerosos nos anos de 2011, quando se propôs na edição o eixo norteador Plano Nacional de Educação, para as reflexões nesta modalidade. Nos Cadernos Cedes os períodos de maior ocorrência do tema foram 2007, quando duas edições tiveram como eixo norteador a Educação de Jovens e Adultos e a Educação no Campo, e em 2015 e 2016, quando o eixo norteador foi a Educação de Adultos e a Educação no Sistema Prisional. Percebe-se a mobilização dos debates para a modalidade EJA em momentos da história em que as perspectivas de luta foram ampliadas; a questão da EJA no Plano Nacional de Educação em 2011, assim como a Educação no Campo em 2007 e a questão da Educação no Sistema Prisional, em 2016. As reflexões se adensaram com o tema EJA, na perspectiva do ensino profissional, com vários textos abordando o PROEJA e a educação profissional. As reflexões sobre o conteúdo de cada texto apontou para uma manifestação atualizada da modalidade, decorrente do posicionamento autoral que se consolidou em abordagens que traduzem a EJA como um direito do cidadão; apontando uma prática emancipadora, onde os docentes devem entender 0 carater peculiar da modalidade, reconhecendo a experiência de vida do educando e priorizando abordagens que permitam motivar e mobilizar o educando para o processo de ensino e aprendizagem. Todos os textos foram concebidos pelos autores com uma perspectiva crítica, ressaltando a potencialidade que tem a modalidade em propor novos significados (de vida, inclusive) para os educandos.

\section{Referência Bibliográfica:}

SPOSITO, Marilia. A luta por educação nos movimentos populares. São Paulo:Hucitec/Edusp, São Paulo, 1993.

UNESCO. Alfabetização de Jovens e adultos no Brasil: lições da prática. Coordenação Técnica Timothy Ireland. Brasilia, 2008. 